\title{
Women Entrepreneurs in Developing Nations: Growth and Replication Strategies and Their Impact on Poverty Alleviation
}

\author{
Hina Shah and Punit Saurabh
}

\author{
"If by strength is meant moral power, then woman is") \\ immeasurably man's superior.
}

Mahatma Gandhi (1869-1948)

Leader of the Indian independence movement

\begin{abstract}
The need to improve the status of women and the promotion of women's roles in development are no longer seen merely as issues of human rights or social justice. Investments in women are now widely recognized as crucial to achieving sustainable development. Economic analyses now perceive that low levels of education and training, poor health and nutritional status, and limited access to resources not only repress women's quality of life but limit productivity and hinder economic efficiency and growth. Therefore, the development of opportunities for women is imperative, not only for reasons of equity but also because it makes economic sense and is "good development practice". The article describes the status and background of women in South Asia and highlights the need to create women entrepreneurs for poverty alleviation. Although some women do start micro-level businesses to support themselves and their families, the contribution is minor and many of these businesses are unlikely to grow or are not viable over the long term. Thus, this article focuses on women entrepreneurship development programs in light of the challenges and regional variations facing women entrepreneurs in South Asia and identifies nine areas where such programs can be strengthened. Their successful replication and implementation, in India specifically and South Asia generally, is discussed for an international audience to raise awareness of the challenges women and support institutions have faced in achieving success in fostering women entrepreneurship. It is hoped that this narration of the Indian and South Asian experience will assist in its replication in other developing nations.
\end{abstract}

\section{Introduction}

Across the globe, women entrepreneurship development has acquired significant attention in recent years. The next decade could see increased effort in this direction due to objectives of regional balance and employment. Reasons for the increased interest in fostering women entrepreneurship include:

1. The acceleration of economic growth requires an increased supply of women entrepreneurs (Shah, 2012). Women entrepreneurs, when successful, act as a changemaker in their families and society and inspire others to become self reliant and take up entre- preneurship. Their success helps families, society, and local and regional economies by contributing to the growth of the nation. As cited by VanderBrug (2013), women in emerging markets plough back 90 cents of every additional dollar of income into "human resources", which includes their families' education, health, and nutrition (compared to $30-40 \%$ for men), thereby helping their families, communities, and nations. However, this supply has not been rapid, consistent, or sufficiently widespread among various strata of the population, especially among women in poverty and hence the need to promote women entrepreneurship development (ICECD, 1999). 


\section{Women Entrepreneurs in Developing Nations: Growth and Replication Strategies}

Hina Shah and Punit Saurabh

2. Past and recent experiences of failures of microbusinesses and non-performance of enterprises have underscored the importance of entrepreneurial competence. Half of the world's population cannot be ignored: women can make an important contribution to business creation (Shah, 2012). Although the percentage of women entrepreneurs in the South Asian region is less than $13 \%$ (Singer et al., 2014), they own $37 \%$ of all businesses the world over and generate $\$ 29-36$ billion USD through businesses in South Asian region alone (VanderBrug, 2013)

3. For the success of microenterprises, especially in manufacturing, development efforts have come to depend more on the person behind the project, the women owner/manager and the entrepreneur. Failures in making significant breakthrough in rural and underdeveloped areas have generally been due to a lack of local women entrepreneurs (Shah, 2013).Thus, there is a need to locate, encourage, and develop women entrepreneurs for accelerated rural development, regional spread of industrial activities, and non-farming employment generation to alleviate poverty.

However, despite attempts to bring out the entrepreneurial capabilities of women, there are substantial challenges that inhibit their capabilities to perform, including:

- lack of access to support networks,

- issues relating to gender or cultural acceptance (Singer et al., 2014)

- lack of basic education

- lack of technical skills and knowledge about business

- lack of market knowledge (making them vulnerable to exploitation by market forces)

Across the globe, the most chronic problems identified by researchers are women's lack of confidence and difficulties in acquiring entrepreneurial skills (Shah, 1996). Another area of concern is the issue of economic sustainability of women-led microenterprises. In the specific context of enhancing the economic position of women, microenterprises refer to income-generating projects that women undertake to advance their own and their families' economic well-being. The enterprises can be classified into two categories: on farm and off-farm (ICECD, 1999). For rural women living in poverty in India, the situation is even grimmer, because it is often exacerbated by exploitation. Because of family responsibilities, certain social customs, values, and practices in some societies, and because of male dominance, women in India often lack exposure to the outside world. Forced to work within a restricted ecosystem, aspiring women entrepreneurs living in rural areas become dependent on middlemen and other agencies, especially if markets are beyond their reach (Shah,1996).

They are also denied equitable access to information, technical know-how, extension programs, training, marketing assistance, credit, and a general opening up of their horizon. As described in a survey report published by the United Nations Conference on Trade and Development (UNCTAD, 2013), "...due to their difficulty in dealing with the life puzzle originated by the need of taking care of family and business at the same time, women entrepreneurs are considered to have relatively lesser experience in terms of handling external business contacts for innovation. However, such difficulties have also enabled women to embrace the opportunities provided by information and communications technologies (ICTs) to create marketing channels, collect customer information and improve efficiencies in their business processes". For example, as per a report to the United Nations Economic and Social Commission for Asia and the Pacific (Shah, 2013), 81\% of women in India use ICT technologies for communication and networking purposes.

We shall now discuss the challenges and regional variations, to what extent women entrepreneurship development programs are effective and successful, and how they can be further improved to alleviate poverty in developing nations. The article draws upon the literature on women entrepreneurship in India but also on the authors' experience in entrepreneurship and in developing programs to foster women entrepreneurship in India while highlighting the South Asian context.

\section{Women Entrepreneurship in Rural South Asia: Challenges and Regional Variations}

South Asia is a vast region with great cultural and economic variations between and within the countries of Bangladesh, India, Pakistan, and Sri Lanka. The same is true with respect to issues relating to women, although it can be said that all women in the region have suffered from the common problem of male dominance, including women in rural areas. 


\section{Women Entrepreneurs in Developing Nations: Growth and Replication Strategies} Hina Shah and Punit Saurabh

But, issues pertaining to microenterprises and entrepreneurship development for rural women in the region have become varied because of variations in economic development between countries. Women from developing countries in the region participate in income-generating projects out of economic necessity and desperation originating from chronic poverty leading to issues of survival for them and their family. They are forced to take the risk, become courageous, to come out of their homes and participate in such income-generating projects. Once they are out of their home and start conducting their own business, the fear of interacting with outsiders appears to recede, along with pressure from family members.

The level of national economic advancement, however, is not the only factor generating variations in the nature and problems with women entrepreneurship in the region. Other factors such as political ideology and cultural barriers have also caused variations. Social attitudes still characterize entrepreneurship as a male endeavour, and discrimination discourages many women from entering private business (Shah, 2013).

Although regional variations should caution us against making general statements about microenterprises and entrepreneur development for women in the region, they should not distract us from discerning common problems faced by the majority of them. These women operate in adverse conditions and overcoming these adversities is of utmost importance as it strikes at the very root of their livelihood. For them, and indeed other disadvantaged women like them, the problems besetting their microenterprises should be given greater attention.

The subsections below examine four of the key factors we identify as obstacles in setting up a microenterprise in India specifically and South Asia generally: i) production technologies and skills; ii) financial resources; iii) marketing and product development; and iv) management.

\section{Production technologies and skills}

For women living in poverty, one main concern is access to production technologies that are appropriate for their restrictive conditions, but they are seldom made available (Shah, 1996). For on-farm enterprises, appropriate production technologies typically include: those that relate to subsistence food crops and small animals; those that take into account women's labour availability and workload as a constraint; and those that con- sider women's preferences as the intended users of the technologies. Thus, the development of such production technologies would recognize, for instance, the role that women play in weeding and thinning of crops and the increasingly limited time that farm women have for such activities on account of increasing male migration. Similar gender-sensitivity is required in developing production technologies for off-farm enterprises. For example, an improved weaving device in India that required eight hours operation a day to make it profitable was rejected by women who only had two to four hours to spare for this particular activity (Carr, 1991).

However, it must be noted that production technologies that save time and lighten workloads may have the counter-productive impact of displacing rural women altogether. For example, technological attempts to improve productivity in poultry have effectively removed women from poultry businesses in many countries as men were better able to profit from the innovation (Acharya, 1981). This means that care must be taken in innovating with production technologies so that improved techniques really mean improved benefits for women.

In many other countries, improved production technologies are badly needed but on the condition that they make do with local raw materials, local producers' skills, existing market demands, traditional distribution and marketing channels, local institutions and their functioning, and local system of production. Finally, although a number of institutions have been carrying out numerous studies into appropriate and improved technologies for microenterprises, such as for food processing and packaging, fibre extraction, fodder production, firewood production, mulberry cultivation as well as reeling and spinning of silk, strategic gaps in applied research remain in the region.

\section{Financial resources}

Entrepreneurs need money to buy the inputs for their production. If they do not have this capital, then they can borrow from financial institutions that lend out money by using their assets as collateral. Thus, financial resources are not a major obstacle for entrepreneurs that have the required collateral and guarantors. However, few women living in poverty in South Asia are able to overcome this obstacle. In India, Pakistan, Bangladesh, and Sri Lanka, for example, many rural and agricultural women face substantial problems accessing credit for the purpose of starting up or running 


\section{Women Entrepreneurs in Developing Nations: Growth and Replication Strategies} Hina Shah and Punit Saurabh

day-to-day businesses. (Llanto et al., 1991; Bourqia et al., 1991). In India, and its other South Asian counterparts, accessing banking support for starting a business is considered as one of the most difficult tasks, as per the narrative given by entrepreneurs to ICECD. The predicament of women entrepreneurs is the result of various constraints posed by several quarters, including the procedures of modern banking and financing and the prevailing social and cultural norms working against the women's interests.

Thus, aspiring women entrepreneurs living in poverty are forced to borrow from usurious middlemen. Fortunately, for some of them, there are informal credit sources, of late, which are especially tailored to suit their needs and constraints. Hence, we hear the success stories of client-friendly credit schemes operated by governmental and non-governmental organizations, such as Friends of Women's World Banking Association and Tambon Vieng Women Group in Thailand; the Grameen Bank and the Bangladesh Rural Advancement Committee; the Production Credit for Rural Women in Nepal; the CYCI scheme of ICECD/Commonwealth; and the Working Women's Forum and the Working Women's Credit Society in India (Llanto et al., 1991). The merits of these lenders lie in the fact that their credits are not subsidized but are based on savings mobilization and market orientation of interest rates, which will guarantee self-reliance and sustainability of the project, and will eventually free women living in poverty from dependence on money lenders and external funding support.

Perhaps the most remarkable of funding sources is the Grameen Bank of Bangladesh (grameen.com). The average income of the bank's almost one million borrowers, 92 percent of whom are women, has increased over 30 per cent - a convincing demonstration that women living in poverty are creditworthy. Another testimony to the effectiveness of the banks' approach is that, when it is replicated in other countries in the region, it proves to be even more successful judging by the percentage of income increment obtained by the borrowers.

\section{Marketing and product development}

The marketability of the products produced by microenterprises of the women living in poverty in the region has been a nagging issue. Market forces are dynamic, and consumers may change their tastes and preferences, hence their demand for particular products may change. Producers need to be innovative in their approaches and strategies if they wish to stay in business for long. Unfortunately, a lack of marketing knowledge remains a major constraint for many women entrepreneurs in South Asia. Some of the examples examined by ICECD show that rural women's microenterprises suffer from several marketing weaknesses. But also, they suffer from poor product design, quality control, and packaging. Delivery, distribution, and networking are other areas of weakness. They do not adequately generate a market and promote their products, and they often fail to constantly improve those products to suit a changing marketplace.

In Bangladesh, the Bangladesh Rural Advance Committee (BRAC; brac.net) puts particular emphasis on a market approach to project design wherein none of the marketing activities in the women's microenterprises operate independently of the others. The final step of selling is always tied to product design by market feedback, which may lead to changes in the product. The approach adopted by the International Centre for Entrepreneurship and Career Development (ICECD; icecd.org) in India is to develop these missing marketing skills in women living in poverty and assist in the selection of non-conventional but market-oriented products. Women are provided with rigorous market exposure, they interact with marketing experts, and they learn to conduct test marketing. They are helped during the initial period of 3 to 12 months not by the Centre marketing their products, but by helping them to create a solid base and network. At the ICECD, women entrepreneurs have demonstrated high sensitivity to market changes and have been quick in adjusting to new demands.

\section{Management}

Managing an enterprise involves planning, budgeting, organizing, staffing, directing, controlling, innovating, and relating to people. In the case of aspiring women entrepreneurs living in poverty, these functions of enterprise management are often not performed entirely and independently by the women producers themselves. Several factors have led to this situation: illiteracy, low educational levels, poverty, lack of exposure to business, and a lifetime of ideological, social, legal, and psychological subjugation. All of these factors have prevented professional women managers from being nurtured and encouraged.

It is the intervening organizations that help to provide direction as problems and opportunities arise, and to make changes if the women's enterprises are not progressing towards their goals. They have to teach the women that enterprises need to be creative, rather than 


\section{Women Entrepreneurs in Developing Nations: Growth and Replication Strategies} Hina Shah and Punit Saurabh

just adaptive, if they are not to remain static. This assumption of the managerial functions by intervening organizations with regard to the women's microenterprises is not always positively perceived and does not produce the desired results. It relates to the commitment and the availability of personnel and funds from the intervening organizations. Some experiences in the region have demonstrated that support from entrepreneurship development organizations does not ensure sustainability and can be counterproductive in many cases (Shah, 2012). For example, we have observed entrepreneurs who were earlier found to be keen in pursuing a business plan, but had to reform their plan (as per the supporting organization's dictate) to such an extent that they lost the motivation to pursue the changed business plan. In some cases, the entrepreneur's reliance on day-to-day support from assisting organizations lead them to lose their self motivation, which negatively affected the pursuit of their business goals.

\section{Potential for Fostering Women Entrepreneurship}

Surplus labour, especially among young people and women living in poverty is a great liability but can become an asset once those with potential are selectively groomed for self-employment and enterprise formation, leading to further job opportunities for others. The socio-economic objectives of decentralizing ownership of businesses cannot be served unless non-traditional sources of entrepreneurship are tapped. The entrepreneurial base will have to be widened by making it possible for all to share opportunities for owning businesses. This goal cannot be achieved by credit and promotional efforts alone, given the socio-cultural impediments facing women in developing nations. Interventions through a women entrepreneurship development strategy for poverty alleviation are needed to bring out women entrepreneurs and nurture and sustain them, through efforts such as training and counselling, developing an appropriate environment, and providing support. Women entrepreneurship development is a human resource development task of the highest order in which the process deals with human motivation, skills, competencies, social and economic risks, and investment of financial and physical resources for a target group, which has been subjugated for centuries. The sensitivity required in handling these tasks in creating, nurturing, and supporting women entrepreneurs from traditional and non-traditional sources has to be recognized by all concerned.
Women entrepreneurship development programs for poverty alleviation combining motivation, training, and counseling, are already well known as an effective tool (Shah, 2013). The major thrust now has to be on what more can be done. Improving the effectiveness of the ongoing efforts, simultaneously widening the programs to cover a wider variety of target groups and regions, and new thrust areas should therefore be given prime focus while analyzing future needs for replication.

Women entrepreneurship development, at the same time, cannot be limited to training. Training is only one way of expanding the entrepreneurial base of a country. Other avenues must also be explored. The environment plays a critical role for all entrepreneurs (trained or untrained and new or existing) for their survival and growth. In the latter part of this article, therefore, some issues and needs to improve the environment to facilitate the emergence of women entrepreneurs, nurture and foster their growth of women entrepreneurs in general are also discussed.

However, there is a no reliable record of who conducts how many women entrepreneurship development programs in a year and, therefore, what is the total output in terms of number of new women entrepreneurs developed and enterprises set up every year in this vast region. Over 1000 organizations are involved in women Entrepreneurship development. In the next section, we will discuss how the impact of such programs and organizations can be evaluated and assessed.

\section{Evaluation and Assessment of Impact}

Assuming for the time being that having a large number of organizations to alleviate poverty through women entrepreneurship is an unavoidable phenomenon in many developing countries, the foremost questions that must be answered are: What are the results? Are they satisfactory? Can we do better? Though the ultimate test of women entrepreneurship development programs is not just how many women entrepreneurs set up enterprises, but how many survive and grow over a period of time. The performance of such programs in most countries and by most organizations leaves much to be desired. Without claiming reliability of data in absence of any systematic studies, our experience working with women entrepreneurs in India indicates that well under half of the women living in poverty who are trained in entrepreneurship programs ultimately set up enterprises. 


\section{Women Entrepreneurs in Developing Nations: Growth and Replication Strategies} Hina Shah and Punit Saurabh

Not only there is substantial wastage of resources and efforts, when so many trainees do not set up enterprises, but the credibility of the whole effort is further affected, thereby discouraging new-corners and the support institutions, particularly those who share the cost of these programs. However, there can be no fixed percentage as a minimum satisfactory level. Although it is recognized that, in rural areas or when dealing with under-privileged communities, rural poor, or tribal groups or women, initial efforts yielding, say 30 per cent results is not bad, we must raise our expectations in terms of results for all other target groups. This need to raise expectations is especially important when poor results are due to poor training and support.

\section{Long-Term Funding and Labour Issues}

At the international level, a consciousness must be created that ambitious unrealistic quantitative targets, if not achieved through proper quality of selection and training and implementation support, would create more frustrations among the high percentage of nonstarters, and may discourage many others from taking up entrepreneurial careers.

The focus on women entrepreneurship development programs must be on commercial manufacturing or service activities that amount to setting up a microenterprise of some sort that has potential for further employment generation. This effort must be distinct from information-giving awareness programs, which are essentially promotional efforts and do not directly develop women entrepreneurs. Any debate on developing women entrepreneurship, therefore, must focus on what it takes to develop an entrepreneur, who, in turn, must set up a business. Without this clarity, this sensitive qualitative human resource development task is bound to become diluted and become a mechanical training exercise.

1. Based on the learning acquired from our experiences, we believe that impact-generating women entrepreneurship development programs require expert handling from conceptualization to implementation , which must be carried out in a composite and continuous manner to cover: Sound promotional efforts before the program to encourage potential women entrepreneurs to come forward

2. Proper selection (not everyone is capable of being an entrepreneur)
3. The establishment of links between the woman entrepreneur and a viable business opportunity and support in developing it. This integrated process of developing women entrepreneurs requires a competent trainer-motivator possessing: i) certain personality traits and behavioural qualities to act as leaders, counsellors, and motivators; and ii) adequate knowledge about business, sources of information, and support system and skills to perceive the potential in aspiring women entrepreneurs, opportunities in the region, and capabilities to mould potential women entrepreneurs into owners of enterprises into a systematic business plan

4. Developing motivational and entrepreneurial capabilities

5. Developing managerial capabilities in women entrepreneurs

6. Providing necessary information, counseling, and follow-up support throughout the creation phase of the business and beyond.

Strengthening Women Entrepreneurship Development Programs

If women entrepreneurship development programs are important for human resource development for poverty alleviation by enlarging the number of enterprises, there should be a stronger commitment to the programs and more systematic planning. In India, such programs have been made an integral part of industrial development (through the government's Five-Year Plan) because they serve a variety of important objectives for self employment, development of rural and under-developed areas, and benefiting less privileged groups, including women. This section identifies nine areas where women entrepreneurship development programs can be strengthened.

\section{Enhancing institutional support}

It is important that women entrepreneurship development programs to foster the creation of manufacturing or service microenterprises be supported by more than just the government; support from key banking and financial institutions and other assistance agencies is required by women entrepreneurs. If possible, program budgets could be shared by these agencies. Sharing costs would help improve the efficiency of these organizations in helping women entrepreneurs. Both the 


\section{Women Entrepreneurs in Developing Nations: Growth and Replication Strategies} Hina Shah and Punit Saurabh

trainers and women entrepreneurs would also become more confident in their effort because of the involvement of these support organizations in their endeavour.

\section{Building up the support infrastructure}

At an organizational level, it is essential that women entrepreneurship development is taken up by more specialized organizations that have a stronger commitment to this activity. Unfortunately, countries in South Asia, such as Vietnam, Bangladesh, and Sri Lanka, along with India, still have a long way to go in setting up specialized entrepreneurship centres dedicated to women. A different culture is required to promote, motivate and develop sustainable infrastructure for fostering women entrepreneurship. A band of dedicated trainer-motivators is key to this program. A great deal of improvisation, innovation, and learning from experience is called for. The organization and the trainers must be doing training and development work continuously rather than an existing officer "spared" for a program here and there. The scale of operations within any country will have to be fairly large, because the entrepreneurial potential among women living in poverty is high even in the most underdeveloped regions.

The specialized organizations that provide women entrepreneurship development programs, therefore, will have to be set up with adequate human and financial resources. In India, with a basic initiative from ICECD and support from a number of financial organizations in many other countries such as Sri Lanka, Pakistan, Bangladesh, Nepal, Philippines, and Thailand, these organizations have so far helped women launch many enterprises, but there is much work left to be done. Women from Indonesia, Sri Lanka, Malaysia, and India have highlighted the need for capacity-building support; they have also identified the need for basic skills in bookkeeping and accounting as well as assistance in removing other such constraints that prevent them from taking advantage of available opportunities (Shah, 2013).

\section{Enlarging the cadre of trainer-motivators}

It is a strategic weakness in women entrepreneurship development efforts that a large number of programs focus only on technical training or only provide credit for women living in poverty. Sometimes, organizations provide marketing for the women entrepreneurs and make them only wage-earning beneficiaries. There is a need to select and groom new trainer-motivators to provide a broad spectrum of support to help women entrepreneurs start and grow microenterprises throughout South Asia.

\section{Identifying opportunities}

One of the more urgent needs is to identify a variety of tiny, micro-, and small-scale project opportunities that the women entrepreneurs can take up. This is necessitated by the fact that new women entrepreneurs in the region - due to their limited educational background, vision, and capabilities - need the help of support organizations to identify opportunities. Many of these entrepreneurs have very limited resources, and support agencies intend to firm up the opportunity without wasting their precious resources accumulated for the venture. Adequate advance work needs to be undertaken in identifying prospective projects to suit local entrepreneurial needs in terms of investment, technology, skills, resources, and markets. This function has to be undertaken in a decentralized fashion location-wise. Most of the existing organizations are ill equipped for this work and will need training in project identification strategies.

\section{Training and counselling}

Given the supply of competent trainers, inventory of project possibilities, and untapped potential of aspiring women entrepreneurs, the development tasks then require counselling and teaching material in local languages. This is where a major gap exists. Training manuals, training materials, audio-visual aids, etc. have been developed by many organizations, especially by ICECD over last 27 years. It should be the task of country-level trainers to translate available training material to suit the requirement of the region. Adequate funding will have to be ensured for this work.

\section{Identifying candidates for entrepreneurship}

A major thrust of women entrepreneurship in most Asian countries is for under-privileged groups of women. However, it has to be recognized that not everyone can be turned into an entrepreneur. Programs can identify aspiring entrepreneurs with good potential for success and provide them with training, counselling, and support to set up businesses. Others may be better suited to employment opportunities. Therefore, our major thrust should be to accelerate the number of tiny, micro, and small enterprises, and therefore, supply a first generation of women entrepreneurs from rural or urban areas, who in turn, will generate jobs for others. Given their socio-economic constraints, it is often the rural woman living in poverty who seek employment or selfemployment. This trend needs further encouragement through appropriate changes in the institutional financial assistance schemes, which at present, are often not liberal enough to recognize a woman as a genuine selfdependent business owner. 


\section{Women Entrepreneurs in Developing Nations: Growth and Replication Strategies} Hina Shah and Punit Saurabh

\section{Supporting women entrepreneurs through to operation} So far, the focus of women entrepreneurship development programs has been on individual development. At ICECD, we emphasize the importance of selection, followed by behavioural inputs to develop motivation in the person to take up entrepreneurship and succeed as an entrepreneur. What began as an experiment in a State of Gujarat in India in the late 1970s has now become a national and international movement. The spread of women entrepreneurship development programs is a result of recognition and financial support provided by the governments, financial institutions, central banks, and the development corporations and banks, bilateral, and multilateral donors, and many others. This movement also has been professionally and qualitatively strengthened by the setting up of resource organizations such as ICECD and many other organiza- tions in the South Asia region. Box 1 illustrates an example of an entrepreneur who initiated the process of entrepreneurship with the support of ICECD.

\begin{abstract}
8. Fostering an entrepreneurial culture and environment To ensure a future supply of entrepreneurs, an entrepreneurial culture and spirit should be encouraged in families from early childhood. Further, the overall environment, especially the policies, schemes of assistance, and their implementation, must induce and encourage women entrepreneurship. In spite of the first recommendation reflecting a long-term goal, the second one offers scope for early actions for the benefit of all women entrepreneurs, whether trained or untrained, whether starting tiny, micro, or small enterprises. Once we create the first generation of women entrepreneurs, the business environment will change and the entre-
\end{abstract}

Box 1. The case of Anita Amitbhai Hudda, woman entrepreneur in electrical goods manufacturing

Anita Amitbhai Hudda is a 47-yearold woman living in the city of Ahmedabad in India's westernmost state of Gujarat. She has been a creative person from the very beginning and graduated from her local college. She married a local businessman, Amitbhai Hudda, but was otherwise undecided on what to do after finishing her education. In 2009, her husband insisted that she utilize her creative skills for some gainful purpose. Having found that she was not able to receive any technical support from her family, friends, or neighbours, she finally came across the Aga Khan Foundation (akdn.org/akf), a globally reputable social entrepreneurship organization working for the economic and social welfare of men and women from local communities. The Aga Khan Foundation helped her to take up the Entrepreneurship Development Program at ICECD with full sponsorship support. At ICECD, she initiated the learning process of creating a business plan. This process helped her tremendously with idea generation and opportunity recognition. She finally zeroed in on the opportunity of manufacturing innovative iron pipes for electrical lighting and other electrical equipment. Such products were sometimes hard to find, and even if they were available, they were not available cheaply. Moreover, the existing products available in the local market lacked both quality and innovation.

She initially invested a small sum of INR 100,000 to set up a manufacturing plant within the periphery of her house with additional support from her husband. Gradually, she was able to hire two people to assist her with the manufacturing process, which was very complex and demanded domain skills. Because Anita had interned at one of the local manufacturing units, she utilized this knowledge to great advantage. She gradually introduced a product mix, diversifying from manufacturing electrical pipes to manufacturing different types of rubber clamps and fasteners. Her unit presently manufactures fan down rods and street lighting equipment along with the associated electrical fittings. The demand for electrical fittings is high be- cause of the booming housing and infrastructure sector in Ahmedabad. These items are readily available through the electrical goods wholesale and retail markets.

Today, after give years in business, Anita is a successful businessperson with a turnover of INR 5 million. She has 700 dedicated customers in Ahmedabad, and her sole proprietorship has flourished from a small garage to an expanded manufacturing unit. She supplies to well-known companies through IndiaMart, with orders flowing from all over India. She has employed 12 men along with two women in her manufacturing unit, in addition to contributions from her son and her husband. Her success has inspired her son to pursue commerce education, and he too is looking forward to become an entrepreneur like his parents.

Anita has plans to establish her own factory at the Changodher industrial area, and she credits her success to her family members and supporting organizations such as ICECD and the Aga Khan Foundation. 


\section{Women Entrepreneurs in Developing Nations: Growth and Replication Strategies} Hina Shah and Punit Saurabh

preneurial thinking will exist in families, and a new generation of children will begin thinking along these lines. This pattern was evident in the case of entrepreneur Smita Jani, who became a successful technology entrepreneur manufacturing multimeters and inspired her son to open his own enterprise in mobile phone repair (Shah, 2013).

The present strategy of developing women entrepreneurs focuses on uneducated rural and urban women who are living in poverty. The time has come for an effort to inculcate a spirit of enterprise, self-dependence, creativity, and high goals among women in developing nations. Because the social fabric changes slowly, interventions are needed, and the first step is an educational policy. Entrepreneurship should be made part and parcel of the education curriculum.

\section{The entrepreneurial environment}

Despite a large number of organizations to promote and assist women entrepreneurs and a variety of schemes to attract and facilitate them, the environment is still not sufficiently conducive for women entrepreneurs to actually set up enterprises. Often, an entrepreneur has to go through a complex set of procedures and formalities to start a business, which not only create irritations and delays but frustrate her efforts until she is exhausted. An urgent need, therefore, is to simplify procedures and formalities. Part of the problem is one of attitudes, which are built on regulatory roles rather than developmental roles. All these agencies need to be gender sensitive. Part of the answer lies in developing the need to inculcate an extension approach among operational level offices of all assistance agencies. ICECD's recent efforts, therefore, in conducting extension motivation and entrepreneurial orientation and gender sensitization programs for such officers, is consistent with the broad view that good training can help create better and more dedicated trainers who can bring the desired change through entrepreneurship.

\section{Conclusion}

In conclusion, it can be said that, although some successful strategies have been evolved, much still has to be done in the effort to alleviate poverty by developing women entrepreneurs in the countries of the South Asia region. The overall impression one sets is that, in the countries of the region, the survival and sustainability of the women's microenterprises depend overwhelmingly on external supports, all the way from generating appropriate production technologies and skills to financial support and access to credit to mar- keting and enterprise management. In one sense, these factors hold true for all enterprises, whether micro, small, medium, or large. However, the capabilities of the women living in poverty are the crucial factors. Those who are capable and possess the skills and knowledge have fought through the non-conducive environment and have progressed.

No one should dispute the imperative of effective external support systems without which the povertystricken and much disadvantaged women could not even survive. But, after managing to survive, where do the women's microenterprises go to and what directions should they take? What is empowerment for the women if it means permanent dependency on others? Real empowerment can come only through capacity building and independence. These are vital questions that should be asked as we reflect on the future of women's microenterprises in the region, especially where it concerns aspiring women entrepreneurs who are currently living in poverty. Women entrepreneurship development programs, when successfully implemented, help us provide the answers. On the whole, women entrepreneurship development programs help enterprises to graduate from being basic income-generating projects to sustainable businesses at preservation levels, and then gradually to enterprises that are focused on growth and raise expectations for economic development and the alleviation of poverty in developing nations.

\section{About the Authors}

Hina Shah has been an entrepreneur since 1978 in the field of plastic packaging. She is currently Director of the International Centre for Entrepreneurship and Career Development (ICECD) in Ahmedabad, India. In 1986, she has transformed her own entrepreneurial experience into this developmental initiative, which has facilitated thousands of disadvantaged youth, with a special focus on women, in becoming entrepreneurs in India and around the world.

Punit Saurabh is senior faculty member at International Centre for Entrepreneurship and Career Development (ICECD) in Ahmedabad, India. His research interests include innovation management and entrepreneurship development, and he has varied experience in product funding and commercialization. His interests also include international affairs, healthcare, and women entrepreneurship. 


\section{Women Entrepreneurs in Developing Nations: Growth and Replication Strategies}

Hina Shah and Punit Saurabh

\section{References}

Acharya, M., \& Bennett, L. 1981. An Aggregate Analysis and Summary of 8 Village Studies. The Status of Women in Nepal. Volume II, Part 9. Kathmandu, Nepal: Centre for Economic Development and Administration.

Bourqia, R., Long., L., \& Smith-Saulniers, S. 1991. A Women in Development Portfolio Review: USAID/Morocco. Volume 1 - Main Report. United States Agency for International Development.

Carr, M. 1991. Women and Food Security: The Experience of the SADCC Countries. London: Intermediate Technology Publications.

ICECD. 1999. Study of Credit Flow and Its Utilization by Rural Women in Micro Enterprises. Report submitted to the National Bank for Agriculture and Rural Development (NABARD). Gujarat, India: International Centre for Entrepreneurship \& Career Development.

Llanto, G. M., Geron, P. S., \& Tang, M.-C. G. 1999. Directed Credit Programs in the Philippines: The Experience and Policy Reform Issues. Report submitted to the Credit Policy Improvement Program and the National Credit Council, Department of Finance.

Singer, S., Amorós, J. E., \& Arreola, D. M. 2014. Global Entrepreneurship Monitor 2014 Global Report. London: Global Entrepreneurship Research Association.

Shah, H. 2012. ICECD: Achieving Convergence for Empowerment of Women. Paper presented at the Western Regional Conference of the National Mission for Empowerment of Women, 23-24, April.

Shah, H. 2013. Creating an Enabling Environment for Women's Entrepreneurship in India. United Nations Economic and Social Commission for Asia and the Pacific (UN ESCAP), South and South-West Asia Office. South and South-West Asia Office. Development Papers 1304.

UNCTAD. 2013. A Survey on Women Entrepreneurship and Innovation. Geneva: United Nations Conference on Trade and Development (UNCTAD).

VanderBrug, J. 2013. The Global Rise of Female Entrepreneurs. Harvard Business Review, September 4, 2013. Accessed August 6, 2015:

https://hbr.org/2013/09/global-rise-of-female-entrepreneurs

Citation: Shah, H., \& Saurabh, P. 2015. Women Entrepreneurs in Developing Nations: Growth and Replication Strategies and Their Impact on Poverty Alleviation. Technology Innovation Management

Review, 5(8): 34-43. http://timreview.ca/article/921

\section{(cc) BY}

Keywords: women entrepreneurship, women entrepreneurs, poverty alleviation, developing nations, women entrepreneurship development programs 